\title{
Current practice in the Histology practical classes of Anatomy inthe undergraduate medical education in 15 Bangladesh
}

Dr. Rukshana Ahmed' ${ }^{l}$, Prof. Khondker Manzare Shamim², Prof. Dr Md HumayunKabir Talukder ${ }^{3}$, Dr, Kazikhairul Alam, Dr. Tahmina Nargis ${ }^{5}$

\begin{abstract}
Background: Histology in the broader sense is devoted to the study of the micro anatomical structure of cells, tissues and organ systems. One of the major areas of laboratory teaching in the medical curriculum is Histology. This study aimed to assess the current practice of teaching learning in Histology practical classes of Anatomy in undergraduate medical education in Bangladesh.

Methods: This descriptive type of cross sectional study was carried out in ten (four government and six non-government) medical colleges from January 2014 to December 2014. Direct observation of 30 Histology practical classes were made by the researcher herself. Different aspects of the classes were scored following a structured checklist by using a four point rubric.

Results: The study findings revealed that the status of the 'light' of the classroom required very minimal efforts for attaining a good standard. On the other hand, observations revealed that considerable efforts are needed to reach a good standard towards 'grouping' of the students in the class and making proper 'conclusion' of the teaching session. Regarding the rest of the issues, it was found that only some or moderate efforts are required for getting to such standards.

Conclusions: The common barriers found in this study were lack of training of teachers, large number of students and inadequacy of modernized teaching-learning aids. So in order to increase the effectivity of the practical classes modern techniques should be practiced. In addition teachers should be equipped with adequate knowledge on teaching pedagogies through frequent training and orientation programme in laboratory teaching.
\end{abstract}

Key Words: Histology, practical

\section{Introduction}

Human anatomy is the scientific study of the form, position, size and relationship of the structures in the body. It can be divided into gross anatomy, histology embryology and neuroanatomy (Brentonet al.2007).Studying histology with a curious eye and mind will improve the diagnostic and clinical abilities of medical students accordingly. So a firm foundation in histology continues to be essential for recognizing and interpreting their changes in disease.

Practical and laboratory classes are often regarded as an essential component of science based courses (Newble and Cannon 1994). Anatomy courses are laboratory based and the laboratory is an outstanding small group, faculty/student interactive opportunity (Drake1998). The practical work in histology is aimed at teaching learners to identify different cells and tissues. The reason behind this is that learner must know what normal tissue and cells look like so that they can

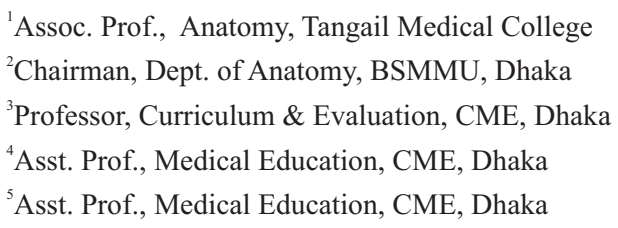

recognize pathological tissues (Ackermann 2004).The laboratory has always been an excellent setting where group of students learn to work together as a team, working through and discussing problems as they proceed (Drake et al. 2002).

The practical teaching of histology in universities has undergone a major revision over the past decade (Cotter2001; Jacyna 2001). The changes are: shift from conventional role of teacher, changes in learning styles, innovative curriculum model and changes in assessment philosophy, methods and tools (Harden and Crosby 2000). The modern trend in Histology is to use computer-aided learning and virtual microscopy (Bloodgood and Ogilvie 2006; Cotter 2001; Paulsen et al .2010).

Teaching and learning of cell biology and histology have gone through remarkable changes. The undergraduate medical courses in Bangladesh have incorporated some of these changes but seem to have some more way to go. Efforts should be made so that student gains learning experience about things and events to face real life situation. Our aim in teaching medical microscopic anatomy is to train students so that they will be competent enough in any setting with graduates taught by traditional or nontraditional method.

Ackermann (2004) stated that many learners do not attend the practicals and many learners also leave the practicals before the end. Finding shows that the majority of students indicated attending practicals as their least favourite way of . 
If the hypothesis that histology is not a popular subject is true, we have to find out whether problem lies within the design or the delivery of teaching instruction.Keeping these in mind, this study was designed to assess the current practice of Histology practical classes of Anatomy in the undergraduate medical education in Bangladesh.

\section{Methods}

It was a cross sectional type of descriptive study, conducted in conveniently selected 4 government\& 6 non-government medical colleges for one year (January 2014 to December 2014). Total 30 Histology practical classes were observed by the researcherherself. A pre-tested checklist with structured rating scale having rubric was used as the data collection tool. Checklist consist of 15 items arranged in 4 groups such as- A)Physical environment of the class B) Teaching methods used in the class C) Group dynamics of the class D)Teaching-learning aids used in the class .

After collection the data were checked and edited and then were processed and analysed by using the SPSS software (version 17).

For each variable of the checklist, the frequency for each andthe mean score were calculated. Interpretation of the mean score was as follows:

Interpretation of the mean score was as follows:

$5=$ No need of further improvement, as it reached a good standard (arbitrarily set by the researcher)
4 to $<5=$ Very minimum efforts are needed to reach a good standard

3 to $<4=$ Some efforts are needed toreach a good standard

2 to $<3=$ Moderate efforts are needed toreach a good standard

1 to $<2=$ Considerable efforts are needed to reach a good standard

There were no ethical problems because all the information was collected with prior permission of the authority and the respective teacher who facilitated the practical classes. Confidentiality of the data was maintained.

\section{Results}

Findings on the physical environment of the Histology practical classes

Regarding temperature, as shown in Table I, the score was the highest (i.e., 5) in $36.7 \%$ classes and the mean score was $3.80 \pm 1.15$.In case of sufficiency of light, the majority of classes $(53.3 \%)$ achieved the highest score having a mean score of $4.37 \pm .76$. For the presence of noise $43.3 \%$ classes had a score of 4 while another $43.3 \%$ classes also got score 3 with a mean score of $3.40 \pm .72$.On the issue of seating arrangement, $66.7 \%$ classes got a score of 2 with a mean score of $2.20 \pm 88$. On the ground of student-teacher ratio, the score came as 3 for about $43.3 \%$ classes with a mean score of $2.97 \pm .99$.

Table I: Frequency distribution of status attained (score obtained) by the Histology practical classes regarding physical environment $(\mathrm{n}=30)$

\begin{tabular}{lcccccc}
\hline $\begin{array}{l}\text { Physical } \\
\text { environment }\end{array}$ & \multicolumn{3}{c}{ Frequency of classes attaining each score } & & $\begin{array}{c}\text { Mean (SD) } \\
\text { score }\end{array}$ \\
\cline { 2 - 6 } & $\begin{array}{c}\text { Highest } \\
\text { score (5) }\end{array}$ & $\mathbf{( 4 )}$ & $\mathbf{( 3 )}$ & $\mathbf{( 2 )}$ & $\begin{array}{c}\text { lowest } \\
\text { score (1) }\end{array}$ \\
\hline Temperature & $11(36.7 \%)$ & $7(23.3 \%)$ & $8(26.7 \%)$ & $10(10 \%)$ & $1(3.3 \%)$ & $3.80 \pm 1.15$ \\
Light & $16(53.3 \%)$ & $9(30.0 \%)$ & $5(16.7 \%)$ & - & - & $4.37 \pm .76$ \\
Noise & $1(3.3 \%)$ & $13(43.3 \%)$ & $13(43.3 \%)$ & $13(10.0 \%)$ & $1(10.0 \%)$ & $3.40 \pm .72$ \\
Seating arrangement & $1(3.3 \%)$ & $2(6.7 \%)$ & $3(10.0 \%)$ & $20(66.7 \%)$ & $4(13.3 \%)$ & $2.20 \pm .88$ \\
Student- teacher ratio & $1(3.3 \%)$ & $8(26.7 \%)$ & $13(43.3 \%)$ & $5(16.7 \%)$ & $3(10.0 \%)$ & $2.97 \pm .99$ \\
\hline
\end{tabular}

$\mathrm{n}=$ Number of Histology practical classes observed

\section{Findings regarding teaching methods used in the Histology practical classes}

Regarding mentioning of the learning objectives, as shown in Table II,the score was 4 in $43.3 \%$ classes and the mean score was $2.83 \pm 1.17$. In explaining the practical tasks to the students $36.7 \%$ classes availed a score of 3 with a mean score of $3.63 \pm 1.03$. Regarding teaching instruction $46.7 \%$ classes were given score 4 with a mean score of $4.20 \pm .84$. Providing supervision $43.3 \%$ classes got the lowest score (i.e., 1) with a mean score of $2.37 \pm 1.56$. In case of making conclusion to the session $50 \%$ classes got the lowest score with a mean score of $1.87 \pm 1.04$. On the matter of total time management $40 \%$ classes achieved score 4 with a mean score of $3.0 \pm 1.11$. 
Table II: Frequency distribution of status attained (score obtained) by the Histology practical classes regarding teaching methods used in the class $(\mathrm{n}=30)$

\begin{tabular}{lcccccc}
\hline $\begin{array}{l}\text { Teaching } \\
\text { Session }\end{array}$ & $\begin{array}{c}\text { Frequency of classes attaining each score } \\
\text { score (5) }\end{array}$ & $\mathbf{( 4 )}$ & $\mathbf{( 3 )}$ & $\mathbf{( 2 )}$ & $\begin{array}{c}\text { Mean (SD) } \\
\text { scowest } \\
\text { score (1) }\end{array}$ \\
\hline Mentioning of the learning objectives & - & $3(43.3 \%)$ & $4(13.3 \%)$ & $8(26.7 \%)$ & $5(16.7 \%)$ & $2.83 \pm 1.17$ \\
Explanation of the tasks & $7(23.3 \%)$ & $9(30.0 \%)$ & $11(36.7 \%)$ & $2(6.7 \%)$ & $1(3.3 \%)$ & $3.63 \pm 1.03$ \\
Teaching instruction & $12(40.0 \%)$ & $14(46.7 \%)$ & $2(6.7 \%)$ & $2(6.7 \%)$ & - & $4.20 \pm .84$ \\
Supervision & $6(20.0 \%)$ & $1(3.3 \%)$ & $4(13.3 \%)$ & $6(20.0 \%)$ & $13(43.3 \%)$ & $2.37 \pm 1.56$ \\
Conclusion & - & $3(10.0 \%)$ & $5(16.7 \%)$ & $7(233 \%)$ & $15(50 \%)$ & $1.87+1.04$ \\
Total time management & $1(3.3 \%)$ & $12(40.0 \%)$ & $6(20.0 \%)$ & $8(26.7 \%)$ & $3(10.0 \%)$ & $3.0+1.11$ \\
\hline
\end{tabular}

$\mathrm{n}=$ Number of Histology practical classes observed

\section{Findings regarding group dynamics of the Histology practical classes}

In case of formation of group, as shown in Table III, the score was the lowest in most of the classes (53.3\%) and the mean score was $1.97 \pm 1.35$. On the issue of active participation $30 \%$ classes got the lowest score with a mean value of $2.67 \pm 1.37$.

Table III: Frequency distribution of status attained (score obtained) by the Histology practical classes regarding group dynamics of the class $(n=30)$

\begin{tabular}{lcccccc}
\hline $\begin{array}{l}\text { Group } \\
\text { dynamic }\end{array}$ & \multicolumn{3}{c}{ Frequency of classes attaining each score } & & \multicolumn{2}{c}{$\begin{array}{c}\text { Mean (SD) } \\
\text { score }\end{array}$} \\
\cline { 2 - 7 } & $\begin{array}{c}\text { Highest } \\
\text { score (5) }\end{array}$ & $\mathbf{( 4 )}$ & $\mathbf{( 3 )}$ & $\mathbf{( 2 )}$ & $\begin{array}{c}\text { lowest } \\
\text { score (1) }\end{array}$ \\
\hline Grouping & $3(10 \%)$ & $2(6.7 \%)$ & $2(6.7 \%)$ & $7(23.3 \%)$ & $16(53.3 \%)$ & $1.97 \pm 1.35$ \\
Active participation & $3(10 \%)$ & $6(20.0 \%)$ & $8(26.7 \%)$ & $4(13.3 \%)$ & $9(30.0 \%)$ & $2.67 \pm 1.37$ \\
\hline
\end{tabular}

$\mathrm{n}=$ Number of Histology practical classes observed

\section{Regarding teaching-learning aids used in the Histology practical classes}

In case of quality and quantity of microscopes and glass slides, as shown in Table IV, the score was 3 in $73.3 \%$ classes with a mean score of $3.03 \pm .61$. In case of the use of other learning aids the score was 2 in $46.7 \%$ classes with a mean score of $2.37+1.09$.

Table IV: Frequency distribution of status attained (score obtained) by the Histology practical classes regarding teachinglearning aids used in the class $(\mathrm{n}=30)$

\begin{tabular}{lcccccc}
\hline $\begin{array}{l}\text { Teaching- } \\
\text { learning aids }\end{array}$ & \multicolumn{3}{c}{ Frequency of classes attaining each score } & & \multicolumn{1}{c}{$\begin{array}{c}\text { Mean (SD) } \\
\text { score }\end{array}$} \\
\cline { 2 - 8 } & $\begin{array}{c}\text { Highest } \\
\text { score (5) }\end{array}$ & $\mathbf{( 4 )}$ & $\mathbf{( 3 )}$ & $\mathbf{( 2 )}$ & $\begin{array}{c}\text { lowest } \\
\text { score (1) }\end{array}$ & \\
\hline $\begin{array}{l}\text { Microscope \& glass slide } \\
\text { Other aids }\end{array}$ & - & $5(16.7 \%)$ & $22(73.3 \%)$ & $2(6.7 \%)$ & $1(3.3 \%))$ & $3.03 \pm .61$ \\
\hline
\end{tabular}

$\mathrm{n}=$ Number of Histology practical classes observed

Bangladesh Journal of Medical Education 2014;5(1):15-19. 


\section{Discussion}

This cross sectional descriptive study was carried out in Anatomy department of four government and six nongovernment medicalcolleges to study the current practice of Histology practical classes in undergraduate medical education in Bangladesh.

Information was collected by observation of 30 Histology practical classes through a checklist used by the researcher herself.

\section{Physical environment}

The present study findings revealed that, regarding temperature and noise,some efforts are needed to reach a good standard (Table I); in case of light, very minimum efforts are needed (Table I). Rahman (2014) conducted a cross-sectional study on assessing the role of medical teachers in managing teaching-learning situation in the lecture classes in selected medical colleges of Bangladesh. That study includes direct observation of 30 lecture classes. The observer found the lighting condition excellent in $80 \%$ classes which supports the findings of the present study. Moreover Mohammad (2008) in Bangladesh found that there was suffient light in $94.4 \%$ classes which supports the findings of the present study. According to Ahmed (2008), for conduction of small group teaching there should be appropriate physical environment, such as there should be a room of sufficient area for group discussion, sufficient light should be available and any destructive factors such as noise, heat should be controlled. Regarding seating arrangement, the present study findings revealed that moderate efforts are needed to fulfill a good standard (Table I).Denton (1992) asserted that workable seating arrangements can help making teaching-learning easier. They also allow the teacher to more readily monitor students' activities. This can have a significant impact on student behaviour and learning. Present study findings showed thaton the issue of studentteacher ratio, moderate efforts should be given. According to Newble and Cannon (1994), research and practical experience has established that between five and eight students is ideal for most small group teaching.

\section{Teaching methods used in the class}

Present study findingsrevealed that regarding mentioning of the learning objectives, moderate efforts are needed to reach a good standard.The researcher noticed that though $76 \%$ instructors mentioned learning objectives at the beginning of the class but most of them could not deliver it in a proper way. Study of Rahman (2014) that includes observation of 30 lecture classes revealed that according to observer'sfindings,more than half $(53.3 \%)$ of the teachers were marked as unsatisfactory in mentioning of the learning objectives of the session.Study of Mohammad (2008) that involves participatory observation of researcher in 36 lecture classes in six medical colleges of Bangladesh showed that $27.8 \%$ teachers did not mention learning objectives.In explaining the task, researchers' observation revealed that some efforts are necessary to reach a good standard (Table
II). Study findings of Rahman (2014) showed that observer found $80 \%$ teachers were good to excellent in explaining the topic which supports the present study.

Regarding teaching instruction researcher's observation revealed that very minimum efforts are needed to reach a good standard; for providing supervision, considerable efforts are needed to reach a good standard (Table II).

Ansary (2011) in Bangladesh mentioned that supervision appears to be the key to the success of clerkships. Sultana (2012) in Bangladesh opined that often corrective suggestions would greatly improve the acquisition of skills by the trainee.In the present study, researcher's observation revealed that $50 \%$ teachers did not provide summary at the end of the teaching-learning session. It indicates that considerable efforts are needed to reach a good standard (Table II). It is a problem area and should be evaluated more closely. Study findings of Mohammad (2008), which included participatory observation of 36 lecture classes of MBBS course in six medical colleges of Bangladesh, showed that $50 \%$ of the teachers did not summarise the topic which supports the finding of the present study. According to the findings of Rahman (2014), observer noted that 30\% of the teachers were unsatisfactory in providing summary at the end of the lesson. Researcher's observation from the present study revealed that regarding total time management some efforts are needed to reach a good standard (Table II). Study findings of Rahman (2014) showed that $93.3 \%$ teachers were good-excellent in managing time in lecture classes. Finding of present study was somewhat lower than this. The reason may be that practical classes consist of multiple tasks such as giving instruction, viewing microscopic glass slides, drawing / checking practical copy book, providing feedback etc. and that much variations of task is absent in lecture classes.

\section{Group dynamics of the class}

In the present study, the observer noticed that grouping was not done in $53.3 \%$ of the classes(Table III). Mearns et al. (2007) considered that Histology classes may need to move away from the conventional practice and include more groups related and tutor structured activities.In the present study researcher's observation revealed that in $30 \%$ classes active participation was $<70 \%$. It indicates moderate efforts are needed on that aspect (Table III).

\section{Teaching-learning aids used in the class}

Researcher's observation revealed that regarding quality and quantity of microscopes and glass slides some efforts are needed to fulfill a good standard (Table IV). The researcher found high quality microscopes and glass slides only in one institute. In most of the institutes there was scarcity of adequate number of slides. Regarding use of other learning aids researcher's observation revealed that moderate efforts are needed (Table IV). It was observed that mostly the teacher use only text book, atlas and blackboard. There was paucity of poster boards, computers and projectors. 


\section{Conclusions}

In this study after analysing different findings it is felt that the teachers of medical colleges as well as respective authority have not paying proper attention towards some aspects regarding conduction of Histology practical classes. Barriers found in this study are large number of students in a group, lack of trained teaching staff and scarcity of teaching learning aids. Necessary steps must be taken to explore these problematic areas more closely. Barriers should be addressed properly to improve current situation. All teachers who conduct Histology practical class should be provided with the training on small group teaching specially laboratory teaching. Thereshould be provision of quality teaching-learning aids and modern technology should be incorporated along with traditional method to ensure better teaching learning situation.

\section{References}

1. Ackermann PC.The suitability of a multimedia resource for teaching undergraduate histologyina developing country.Thesis (PhD). University of Pretoria.2004.

2. Ahmed A. 2008. Current practice of small group teaching in two preclinical departments of medical colleges in Dhaka city.Thesis(MMEd).University of Dhaka.2008.

3. Ansary J A.Views of teachers and students regarding effective clinical teaching and learning in dental education. Thesis (MMEd).Bangabandhu Sheikh Mujib Medical University.2001.

4. Bloodgood R A, Ogilive R W. 2006. Trends in histology laboratory teaching in United States medical schools.Anatomical Record (Part B New Anatomist). 2006; 289:169-175.

5. BrentonH, Hernandez J, Bello F, StruttonP,Purkayastha, Firth T, Darzi A.Using multimedia and web 3D to enhance anatomy teaching. Computers \& Education.2007; 49: 32-53.

6. Cotter J R., 2001. Laboratory instruction in histology at the University at Buffalo: Recent replacement of microscope exercises with computer applications. Anatomical Record. 2001;265(5):212-221.
7. Denton P.Seating arrangements for better classroom management.Adventist education. 1992.

8. Drake R L, Owrie D J, Prewitt CM. 2002.Survey of gross anatomy, microscopic anatomy, neuroscience and embryology courses in medical school curricula in the United States.Anatomical Record (New Anatomist). 2002; 269: 118-122.

9. Drake R L. 1998.Anatomy education in a changing medical curriculum.Anatomical Record.1998; 253: 2831 .

10. HardenR M., Crosby J., 2000. The good teacher is more than a lecturer-twelve roles of good teacher. Medical teacher, 2000; 22(4): 98-132.

11. Mearns K, Meyer J, Bharadwaj A.Student engagement in human biology practical sessions. 2007. Available at: http//Isn..curtin .edu.au/tlf/tlf2007/referred/mearns.html

12. Mohammad S. A situation analysis of current large group teaching in medical colleges in Dhaka city. Thesis (MMEd).University of Dhaka. 2008.

13. Newble D, Cannon R.A handbook for medical teachers. $3^{\text {rd }}$ edn. London: Kluwer Academic Publishers. 1994.

14. Paulsen F P, Eichhorn M, Brauer L. Virtual microscopythe future of teaching histology in the medical curriculum? Annals of Anatomy.2010; 192: 378-382.

15. RahmanM M. Assessing the role of medical teachers in managing teaching learning situation in the lecture classes of selected medical colleges. Thesis (MMEd).Bangabandhu Sheikh MujibMedical University. 2014.

16. Sultana J. Bedside teaching in obstetrics and gynecology department of some selected medical colleges in Bangladesh.Thesis (MMEd).Bangabandhu Sheikh MujibMedical University. 2013.

Bangladesh Journal of Medical Education 2014;5(1):15-19. 